\title{
Second Registers: Maritime Nations Respond to Flags of Convenience, 1984-1998
}

\section{Rodney Carlisle}

\begin{abstract}
En réponse au développement des pavillons de complaisance attrayants pour les navires marchands dans le commerce international, onze pays ont établi les "deuxièmes enregistrements » pour ces bâtiments au cours de la période 1984-1998. Cet article fait état du développement de ces deuxièmes enregistrements et offre une perspective sur leur degré de succès comparé à l'effet des pavillons de complaisance proprement dit. Les détails jètent une certaine lumière sur le processus de la globalisation de l'industrie maritime.
\end{abstract}

In response to the development of attractive flags of convenience for ships in international commerce, eleven countries established "second registries" for ships over the period 1984-1998. This article gives an account of the development of these second registries and offers an assessment of their degree of success in offsetting the effect of flags of convenience. The details shed some light on the process of globalization of the maritime industry.

The eleven registry systems evaluated here are those of Britain (in the Isle of Man), the Netherlands, Norway, France (in the Antarctic Territory of Kerguelen), Denmark, Belgium (in Luxembourg), Germany, Spain, Portugal, the United States (in the Marshall Islands), and Italy. These nations created the new ship registry systems because ship owners in each of the countries had increasingly been transferring the registry of their ships, and often the incorporation of the ship-owning company itself, to overseas flags of convenience.

The reasons why ships had been flagged-out were largely economic. A Norwegian ship owner, for example, could more profitably operate his vessels under the flag of Panama or Liberia than under the traditional flag of Norway. Countries like Panama and Liberia allowed the hiring of crews from anywhere in the world, and they charged registration and tonnage fees, but little or no income tax on the wages of the seafarers or on the ship owning corporation. It was for such reasons that the registry flags of Panama and Liberia were called "convenient." 
The flagging-out of ships from Norway, Germany, and the other traditional maritime nations threatened the domestic economy of the countries to varying extents. With the transfer of companies, the home country lost not only the taxes and employment, but could face the decline of whole ship-related businesses as well. Some of the traditional shipping countries could face economic disaster. In the case of United States strategic rather than economic issues attracted the government's attention. Defense officials expressed concern that ships owned by Americans but registered abroad might not be available for requisition or charter during a military conflict. ${ }^{1}$

The first generation of flags of convenience was supplemented by the creation of new flags of convenience during the shipping boom of the 1960s and 1970s, offering even more inducements and competitive rates to attract ship owners from the traditional maritime states. The years of establishment of open registry systems through the early 1980s are shown in table 1.

Table 1.

\section{Year of Establishment of Open Registry}

First generation of open registry:

1919 Panama

1943 Honduras

1948 Liberia

Open registry in newly independent nations:

1964 Cyprus
1966 Singapore
1973 Malta
1974 Bermuda
1976 Bahamas
1981 Vanuatu
1982 St. Vincent and the Grenadines

The proliferation of flags of convenience was part of a larger phenomenon. In the age of decline of colonial empires after the Second World War, newly independent states sought sources of revenue. In effect, the new countries like Cyprus, Malta, and Bermuda could market their sovereignty. The ship registry systems could generate considerable fees. Many of the new countries also set up such facilities as incorporation and banking centers, offered low or non-existent corporate taxes, and other inducements to foreign capital. In these ways, the proliferation of flags of convenience went hand in hand with the proliferation of tax haven states.

The very terminology used to describe the systems became a matter of controversy. In the United States, a lobbying group for ship owners who had registered their ships abroad preferred the term "flags of necessity," to "flags of convenience." Ship

1 Rodney Carlisle. Sovereignty For Sale: The Origin and Evolution of the Panamanian and Liberian Flags of Convenience (Annapolis: Naval Institute Press, 1981), 193-216. 
owners also preferred the term "open registry," referring to the fact that such registry systems were open to ships owned anywhere in the world. Meanwhile, labor unions in the United States and the other maritime countries protested, usually with little effect, the loss of jobs and the lack of unionization aboard the foreign-registered ships, and the term "flag of convenience" took on more pejorative connotations.

In the twenty years from the mid 1980s through the early twenty-first century, at least another 14 open registry systems were developed, mostly by former colonial dependencies. Many of these systems became notorious for their low wage scales and otherwise exploitative labor conditions. By the 1990s, the London-headquartered International Transport Federation (ITF), a confederation of seafarers and longshoremen's unions around the world, would sometimes declare a particular open registry a "flag of convenience." When they did so, they signaled member unions to boycott, if possible, ships registered in those countries. Some open registry systems, which are known for relatively fair labor practices, have not been designated "flags of convenience" by the ITF. For this reason, the terms "open registry" and "flag of convenience" are not exactly synonymous from the point of view of organised labor. ${ }^{2}$

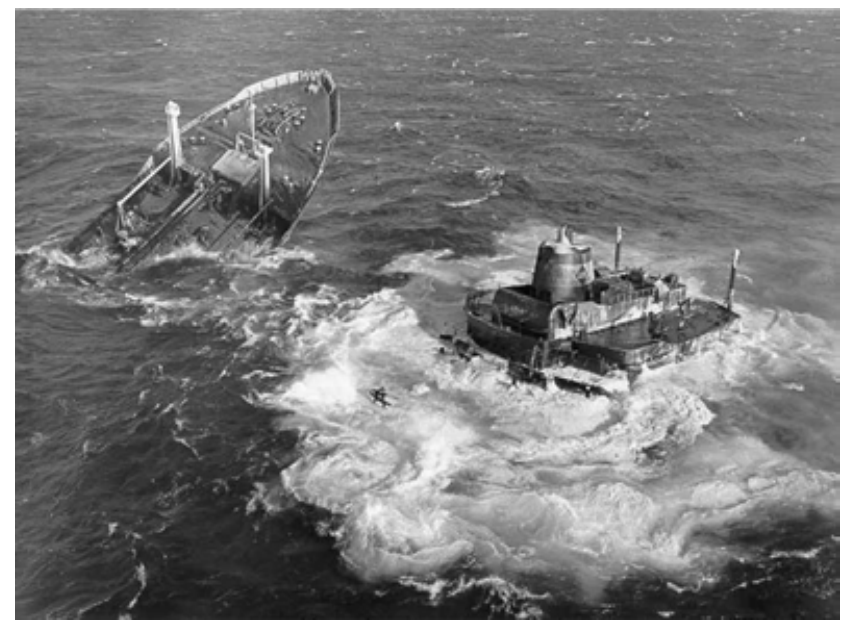

The Argo Merchant, 1976

Photo: USCG

Under the various international conventions governing safety, environmental, and working conditions aboard ship, enforcement of those rules is left to the country of registration, not to the country of the ship-owner. Many of the open-registry nations had no facilities for inspection or did not choose to secure the services of an international firm that would conduct inspections. As a consequence, some of the ships registered in open registry countries had a reputation for unsafe conditions. The sinking and resulting oil spills from several tankers registered in Liberia brought world criticism of that flag as early as the 1960s and 1970s. Among the ships lost were the Torrey Canyon in 1967 off Great Britain, the Argo Merchant in 1976 off Nantucket, and the Very Large Crude Carrier, Amoco Cadiz in 1978 off France. The

2 More than 20 nations had open registry systems as of 2009, and most of them also had taxhaven and incorporation facilities. Since the list of such states is constantly expanding (and sometimes contracting) the following list may not be entirely accurate as of the date of publication of this essay. Most, but not all, of the following open registry systems have been designated flags of convenience by the ITF: Antigua and Barbuda, Bahamas, Barbados, Belize, Bermuda, Bolivia, Cambodia, Cayman Islands, Cook Islands, Cyprus, Gibraltar, Honduras, Kiribati, Liberia, Malta, Mauritius, Mongolia, Panama, Seychelles, Singapore, St. Kitts and Nevis, St. Vincent and the Grenadines, Tuvalu, and Vanuatu. 
flag of Cyprus developed a reputation for taking on older, worn-out ships owned in Greece.

Nevertheless, flagging out continued and reached crisis proportions for some nations in the 1980s. In 1987 both Norway and the Netherlands adopted systems of second registries, soon followed by others, some based in the home country, some offshore, as shown in table 2.

\begin{tabular}{|l|l|l|l|}
\hline \multicolumn{5}{|c|}{ Table 2. } \\
\hline \multicolumn{3}{|c|}{ Year of Opening of Second Registries } \\
\hline Year & Registry & Domestic or Offshore & Primary User \\
\hline 1984 & Isle of Man & offshore & United Kingdom \\
\hline 1987 & Netherlands Antilles & offshore & The Netherlands \\
\hline 1987 & Norwegian International Ship Register (NIS) & domestic & Norway \\
\hline 1989 & Kerguelen (French Antarctica, to 2003) & offshore & France \\
\hline 1989 & Danish International Register (DIS) & domestic & Denmark \\
\hline 1989 & Luxembourg (for Belgian ships, to 2003) & 'offshore' & Belgium \\
\hline 1989 & German International Register (GIS) & domestic & Germany \\
\hline 1990 & Madeira (MAR) & offshore & Portugal \\
\hline 1991 & Canary Islands & offshore & Spain \\
\hline 1992 & Marshall Islands & offshore & United States \\
\hline 1998 & Italian Second Register & domestic & Italy \\
\hline
\end{tabular}

Although the laws and taxation systems of these second registries varied, they had several characteristics in common. The ships would still fly the national flag of the ship-owner's country, or the flag of a semi-sovereign offshore dependency. Secondly, the new registry would allow different manning rules, reducing or eliminating the provision that seamen aboard the ship had to be nationals of the home nation. Further, laws that would guarantee labor union representation of ship-board workers were relaxed or eliminated in some cases. And a new taxation code, both for corporate and income taxes, was drafted for the new second registry. All of these measures meant that the second registers would allow the ship owner to keep his ships under the national flag of the home state or under that of an overseas dependency. At the same time, the owner could operate his ships at costs that were competitive on the world market. This was especially the case because the new second registries allowed the hiring of all or most of the crew on an international basis, often from low-income states like the Philippines. In most cases, but not all, domestic labor unions as well as the ITF found the creation of second registries a highly anti-union practice. However, in some few cases, organized labor actually endorsed the new systems. ${ }^{3}$

3 In addition to the fact that Labor or Socialist governments supported second registries in several countries, labor unions specifically endorsed the second registry system established by Belgium in Luxembourg, discussed below. Furthermore, in a system not reviewed here, labor in Brazil supported the establishment of a special registry in the tax-free zone of Manaus to allow payment of wages in U.S. dollars, to avoid the inflation in Brazilian currency. Brazil established a second registry in 1997, the Registro Especial Brasileiro. 
The second registries at first seemed capable of offsetting the appeal of flags of convenience, simply by offering a competitive structure, with some of the same conveniences and economies. But a close examination of the statistics of ship registry in the 1990s and the first decade of the twenty-first century reveals a far more complex set of developments. For example, when some of the second registries were opened to owners from several countries, those second registries took on some of the characteristics of open registries. Indeed, the ITF declared several of the second registries as "flags of convenience" because of the labor conditions that had developed on ships in those second registries. ${ }^{4}$

During the period of proliferation of both flags of convenience and second registries, a system of port state controls evolved. Conformity to various standards aboard ships at sea had traditionally been enforced by the flag state. With the development of flags of convenience in various newly independent nations, and later even in countries with no seaports and no maritime heritage at all, such as Bolivia and Mongolia, the portstates, rather than the flag states, had to take over inspection and enforcement activities. This meant that the countries with ports at which ships stopped sought to establish some method of placing sanctions on ships that were unsafe, or ocean-polluters, or that had inhumane working conditions aboard.

The first successful system of international port state control was the result of a 1978 agreement, known as the Paris Memorandum of Understanding (MOU), in which signatory countries agreed to inspect a standard percentage of vessels calling at their ports. As the number of ships registered in offshore regimes that had little or no facility for ship inspection increased, the MOU took on greater responsibility. In the 1990s, with the development of the internet, MOU inspection-failure rates and rates of detentions of ships for ordered improvements were widely and promptly disseminated.

Ship owners and shippers were soon able to anticipate that the registry of a ship under certain flags could result in delays and adverse publicity. A delay in port to address repairs required for safety or environmental protection could be costly, reducing the costattraction of open registry in states with bad records. By publishing lists of registries ranked according to their detention rates, it was possible to distinguish between "white list" countries with excellent records of detention (that is, low rates), and grey and black

4 In some cases, the legislation creating the registry was passed in the year before the first ships were registered. Systems not discussed here include those of Brazil (1997), Turkey (1999), and the Hong Kong registry, which is sometimes regarded as a second registry system for the People's Republic of China. South Korea also considered, but did not adopt, a second registry system in 1998. China since 1979 has employed almost four million tons of its merchant fleet through wholly-owned and controlled shipping companies registered and flagged in Hong Kong. Still other Chinese-owned ships have been registered in Singapore. For these reasons, some analysts consider both Hong Kong and Singapore as second registers for China. Michael Clark, "Shipping: an Overview," Oxford Encyclopedia Maritime History, John Hattendorf, ed., vol. 3. Martin Stopford also considers Hong Kong to be a second register of China. He includes it along with Singapore, NIS, Marshall Islands and Isle of Man as among the largest second registers. Martin Stopford, Maritime Economics (New York: Routledge, 2007). 
list countries that had poor records. Thus the published success or failure rate of portstate inspections became a form of sanction discouraging shippers from using ships with poor records, or from using ships registered under the flags of states known to have little regard for the conventions they had signed..$^{5}$

The simultaneous evolution of second registries and the development of additional open registries is an intricate and overlapping story, only partly captured in contemporary maritime news media, and little noted or understood beyond a narrow circle of specialists in the shipping business. Nevertheless, the development of both open registries and second registries and the concurrent appearance of the MOU method of port state control are all significant products of the underlying globalization of world enterprises. By the first decade of the twenty-first century, well over half of all the shipping in the world was registered either in open registry states like Panama, or in the second registers, like the Isle of Man.

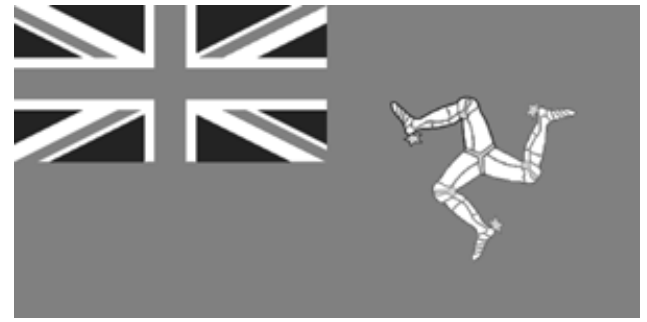

Isle of Man; defaced, white with yellow highlights, red ensign.
The development of second registries in the offshore dependencies of the Isle of Man, the Netherlands Antilles, Spanish Canary Islands, French Antarctica (Kerguelen) and Portuguese Madeira was a striking phenomenon. The legislatures of the home countries found it politically and legally more acceptable to structure a liberalized maritime code for an offshore dependency than to create a wholly new and separate code within the home country. Such an approach, in fact, lay behind the original creation of both the Panamanian and Liberian registries.

In one sense, the original Panamanian and Liberian registries had both been intended as forms of "second registries" for the United States. Both nations had special relations with the United States. Panama was created by secession from Colombia in 1903, with the blessing of the United States. The United States immediately recognized Panama's independence, and then signed a treaty that not only ceded American control of the Panama Canal Zone, but gave the United States the authority to intervene militarily to maintain stability in the country. Liberia had been formed as a colony in Africa for the resettlement of freed African-American slaves in the early nineteenth century by an American charitable organization, the American Colonization Society. The Panamanian registry that allowed foreign-owned ships to register in that country was established in 1919. The Liberian registry was set up in 1948, under the direction of a company established by former United States secretary of state Edward R. Stettinius. Although both countries were independent, to varying extents over time they were dependent on the United States and emulated major American foreign policy positions. As quasi-

5 The operation of this and other MOU systems and their impact have been analyzed in a monograph by Professor Elizabeth DeSombre, Flagging Standards: Globalization and Environmental, Safety, and Labor Regulations at Sea (Cambridge: Massachusetts Institute of Technology, 2006), 87-134. 
dependencies of the United States, both countries attracted American ship-owners. Over time, however, with the distancing of both nations from the U.S., and the transformation of the registries into flags of convenience that attracted ship-owners from around the world, the original "second registry" status of each country's maritime flag has been almost entirely forgotten. ${ }^{6}$

Press releases, public addresses and other commentary by ship owners, maritime analysts, labor representatives, and registry operators suggest how the competition of flag states has come to resemble a private-sector marketplace in commercial services. Some ship-registries frankly operate as businesses, rather than as branches of a government, offering services and competing with one another for the registry of ships from around the world. Statistics of ships and tonnage registered shed light on the degree of success or failure of the new second registries as they competed with flags of convenience and even with each other. ${ }^{7}$

Some of the second registries had limited success in achieving the economic goal of supporting the national shipping industry. Others were more successful, preventing the destruction of the home fleet that otherwise would have happened through transfer to entirely foreign open registries. In several cases, the new second register was so well thought-out and so well managed, that the new registry began to itself attract the registry of ships owned in other nations. In this way, some acted as efficient open registries for well-operated ships. One such success story was the registry of the Isle of Man.

Created in 1984, by 1996 the Isle of Man registry claimed that it was achieving a good level of success, with 170 vessels registered, and with a reputation for accepting only good quality vessels. By adding a section that allowed bareboat charter registry in 1991, the system had gained some 20 new ships. The director of the registry frankly attributed its success to the fact that it charged a one-time fee of 375 pounds sterling when the ship was registered in, together with the cost of a ship survey. With no income tax or further tonnage taxes in subsequent years, the rate was the very lowest charged for ship registry in the mid 1990s. Captain David Ramsbottom, marketing co-ordinator for

6 Full details of these developments are covered in Carlisle, Sovereignty for Sale, 1-18 and 110-133. Andrew Guest recognised the original second register status of Liberia, noting that it "was first thought of more than 40 years ago when Edward Stettinius, a former secretary of state who helped set up the Liberian maritime programme which evolved into the world's biggest flag of convenience." Andrew Guest, "U.S. furore over talk of second register," Lloyd's List, 13 September 1991, 8.

7 An excellent source for running commentary on contemporary competitive developments in ship registry is the British maritime news journal Lloyd's List. Other periodicals consulted include Asia Times, and Business Times (Singapore), as well as news and business periodicals such as New York Times and Financial Times. Specific issues cited below are among hundreds of other issues of these periodicals reviewed for this essay. An excellent source of ship registry statistics is the annual report of the United Nations Conference on Trade and Development, Review of Maritime Transport, herein abbreviated UNCTAD RMT. All of these sources document the competitive marketplace nature of the open registry systems. The commercial and competitive nature of open registry systems is obvious from an examination of the marketing nature of the more than 20 registry websites readily found on the Internet. 
the Manx flag, said "I presume that the Isle of Man register must be financially beneficial since owners are leaving other reputable registers for us. But that is only part of it. The safety track record, the quality of service and the British links are all crucially important. ...We are established as a quality register, and this is becoming more and more important for owners. They are choosing us rather than going for some of the more discredited registers." 8

In assessing the competition between registries, Lloyd's List quoted maritime consultant Stephen Chapman, who had calculated that the least expensive registry for large tankers was in the Isle of Man. Nevertheless, Panama and Liberia, with much more expensive tonnage rates, still had far more tonnage registered. The cost differential, the item noted, "can sometimes give a misleading impression." If cost was the only factor, the Isle of Man would soon have eclipsed the major open registries. But because the registry strictly insisted on safe and correctly maintained ships that conformed to international conventions on environmental conditions, large numbers of international ship owners opted for the much more expensive, but less regulated, flags. ${ }^{9}$

The managers of the Isle of Man registry did not like their system to be considered either as a second register or as a flag of convenience. Colin Douglas, the Director of Marine Administration at the Isle of Man shipping register, said: "We are independent from the UK and do not see ourselves as a second register... We are an international British Register and are not in the same league as second registers. They charge annual tonnage taxes and they are there for reasons of getting around crewing costs and to produce an income for themselves." From his point of view, the registry was simply one of several international services provided under the semi-sovereign status of the island. Even so, the United Nations Conference on Trade and Development (UNCTAD) continued to list the Isle of Man registry as the "second register" of the United Kingdom, as did most shipping law analysts. ${ }^{10}$

Another of the offshore island second registries was that of the Netherlands Antilles. By contrast to the experience of the Isle of Man, the Antilles registry was fraught with difficulties. The Netherlands Antilles became a separate country within the kingdom of the Netherlands in 1954. As a sovereign state, it was composed of five separate islands: Curaçao, Bonaire, and three smaller islands near the Virgin Islands: Sint Eustasius, Saba, and Sint Maarten. The legislation establishing the ship registration system was passed in 1987, with the registry office set up in the port of Curaçao. Despite the competition from other flags, the Netherlands Antilles registry recorded substantial growth in 1993, with 40 new entries in the first eight months of the year. Although the flag administration had not worked on marketing, it attracted roll-on roll-off vessels,

8 Rob Ward and Julian Bray, "Manx register claims success," Lloyd's List, 20 June 1996, 3.

9 “Open Registers: Isle of Man tops low-cost league,” Lloyd's List, 26 November 1993, 8.

10 Robert Ward, "Special Report on World Ship Registers: Distinctions becoming more blurred," Lloyd's List, 11 February 1997; Ademini-Odeke, Bareboat Charter (Ship) Registration (Martinius-Nijogg, 1998), 34 also regarded the Isle of Man as a second register. UNCTAD RMT issues 2003-2007 also explicitly categorize the Isle of Man register as a second register. 
many from Germany. Local administrators hoped to improve the registry further by consolidating services, and to create "one-stop shopping" for ship owners. At that point in the development of the registry, the Netherlands Antilles offered ship owners a choice of fee structure, either $\$ .22$ per ton, with a minimum of $\$ 600$, or an income tax on profits ranging between 7 and 9.6 percent. The registry required a Dutch master of the ship (although that could be waived). Crew and other officers could be of any nationality. ${ }^{11}$

However, through the 1990s, inter-department politics kept the Netherlands Antilles from reaching its potential as a competitive open register. In 1998, administrators complained that discussions of consolidation into a single agency had been going on for at least four years, with little sign of progress. ${ }^{12}$ Continuing in-fighting among maritime agencies in Curaçao led supporters of the registry to hope that various ship services could be combined into one department. ${ }^{13}$

Another political difficulty arose when a series of referenda in 2005 led to a plan to dissolve the Netherlands Antilles into five separate states, planned for 2008. Delays in implementing the plan left it unclear whether the ship registry would remain in Curaçao, the main center for offshore operations, or would lead to several separate registries in two or more of the new states that may emerge from the Netherlands Antilles dissolution. Although open to

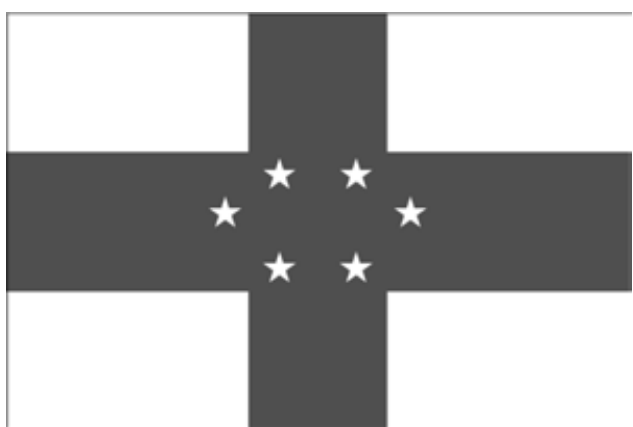

Netherlands Antilles; blue on white. owners from around the world, the Netherlands Antilles flag never emerged as a major open registry.

The case of Belgian ships registering in Luxembourg in the period 1987-2003 varies from the other second registry systems in a number of ways, although it was motivated by the same concern for high costs and for flagging-out of vessels. The system is unique in that Luxembourg is landlocked, with no seaport. Furthermore, Luxembourg, although closely associated with Belgium in numerous economic and diplomatic agreements, is not an "overseas dependency." The complex system was worked out in 1987, with agreement from the seamen's unions of Belgium.

Belgian shipping had been transferring out to various foreign flags in order to be able to reduce labor costs. The losses to foreign flags continued despite efforts by the government to offer subsidies, and several severe court struggles to force Belgian companies to remain Belgian-flagged. Under the 1987 agreement, some 15 ships of Compagnie Maritime Belge (CMB) were flagged in Luxembourg, at considerable cost

11 Tony Gray, "Special Report on Netherlands Antilles: Registry set for growth as marketing moves take off," Lloyd's List, 1 September 1993, 6.

12 John MacLaughlin, "Special Report on Dutch Caribbean: Netherlands Antilles edges closer to ship registry structure," Lloyd's List, 22 September 1998, 9.

13 Bruce McMichael, "Special Report on Ship Registers: Newcomers seek share of the spoils," Lloyd's List, 8 September 1998, 6. 
savings. Seamen could be hired in that country at lower wages, but some of the social security benefits extended to Belgian workers would be picked up by the Belgian company, which operated the ships on charter. The ships were actually dual-registered, in both Belgium and Luxembourg. This unique second registry system was ended in 2003 by Belgian royal decree. ${ }^{14}$

The offshore registry of France also suffered several problems. For one thing, the island of Kerguelen clearly was not a semi-sovereign dependency of France, as it had fewer than 100 year-round residents. In fact, the isolated, semi-Antarctic island cluster may have offered French legislators a convenient fiction - an offshore territory, that unlike the Netherlands Antilles, had no prospect of either dividing into multiple sovereignties or establishing itself as a truly independent sovereign state. Like other maritime states in the late 1980s and early 1990s, France was suffering a decline of its merchant fleet.

In a review of the French shipping industry in 1994, maritime journalist Anthony Dunlop argued that the decline of French shipping "was to some extent shielded" by "internal factors." These included subsidies, and very close relationships between shippers, brokers, and ship owners. Cabotage too, played a part in maintaining a large coastal fleet. Nevertheless, the recession of the 1980s had a severe impact on the shipping industry. Both Socialist and Conservative governments in France attempted to deal with the problem. The Socialists set up the Kerguelen register by an act passed 17 June 1989, but reporters believed that the country did not make the same "commitment to the offshore registry" as Norway and Denmark did to their domestic second registries. For example, the French required that 35 percent of the crew of a Kerguelen-registered ship be French nationals. Even so, all of the French oil tanker fleet moved to Kerguelen, where it could operate at half the cost of French registry. Some French ship owners wanted the Kerguelen registry transformed into a true open registry to compete for international shipping. ${ }^{15}$

When the French government considered establishing a "third" registry in 1999, French unions balked. The seafarers' union of the Confédération Française Démocratique du Travail reacted with hostility to an announcement from Claude Gressier, ports and seaboard director of the Ministry of Transport Shipping, that the government would consider setting up another international register to replace the Kerguelen register. Delegate-general Edouard Berlet of the Central Committee of French Ship Owners said "the Kerguelen register ... had never put French owners on fully competitive level against counterparts in other countries."

Gressier pointed out that, because the Kerguelen register was based in waters not covered by European Union law, companies using it had no access to the European

14 Greta Devos and Guy Elewaut, CMB 100: A Century of Commitment to Shipping, 1895-1995 (Tielt, Belgium: Lannoo, 1995), 251-253. The author thanks Michael Clark for bringing this source to his attention.

15 Ademini-Odeke, 33; Anthony Dunlop, "Long haul to stem the exodus from Gaul," Lloyd's List, 4 April 1994, 2. 
cabotage sector. This, he said, could leave French companies in difficulty in the event that a neighboring country such as Italy decided to use its own second register to offer competition on ferry routes between the French mainland and the island of Corsica. Furthermore, the Kerguelen register was not available to cruise companies, which Gressier suggested was one of the reasons for the virtual absence of French companies in the cruise sector. Although ship owners denied putting pressure on the government to establish a domestic-based register similar to those in Germany, Norway, and Denmark, the arguments in favor of such a registry mounted. ${ }^{16}$

The second registries of Norway (NIS) and Denmark (DIS) were both established as domestic, not offshore, registries. Norway has no overseas semi-independent territories, as do Britain and France. Although Denmark has two overseas dependencies, Greenland and the Faroe Islands, both territories have strong local political movements for full independence.

Between 1983 and 1987 the Norwegian-flagged fleet declined from 34.5 million deadweight tons (dwt) to 10.7 million dwt, and the number of Norwegian merchant seamen declined from 18,500 to 9,500 . With manning under the national flag representing 25 percent of running costs, the existence of Norway's shipping industry was threatened and flagging out became common. The Labor government decided to approach the problem with a second register, the NIS, which allowed foreign seamen to be employed under Norwegian labor terms. Famed shipping magnate Erling Naess (who had authored a major study of flags of convenience some years before), had suggested the system in 1984 as a solution to the shipping cost problem. NIS got underway 1 July 1987, and was credited with preventing a national economic disaster. ${ }^{17}$

Early in the 1990s, shipping analyst Christopher Brown-Humes concluded that the Norwegian and the Danish international registers had done rather well in meeting their goals. The 1987 NIS and the DIS, established 23 August 1988 with "slightly different aims," both had beneficial impacts on their countries' shipping industries. Even so, he believed that NIS was already "past its heyday," noting a marginal drop in tonnage between the end of 1990 and the end of 1991. He believed that the problem of substandard shipping was already plaguing the NIS.

Brown-Humes also noted that Denmark had not only increased registry, but had increased employment of Danish seamen. He concluded that second registers were no panacea, and, to succeed, would have to guard against substandard ships, and be coupled with financial incentives. ${ }^{18}$ In 1996, the Danish register added the inducement of no

16 Andrew Spurrier, "French seamen in register warning: Union says state proposal must not threaten jobs," Lloyd's List, 27 January 1999, 12.

17 Dag Bakka, Hoegh: Shipping Through Cycles (Oslo, Norway: Leif Hoegh \& Co., 1997), 174. The author is indebted to Michael Clark for bringing this source to his attention. Erling Naess authored The Great PanLibHon Controversy (Epping, UK: Gower Press, 1972).

18 Christopher Brown-Humes, "Special Report on World Ship Registers: Striking a balance on quality and cost - Christopher Brown-Humes looks on the progress of 'second registers,"' Lloyd's List, 1 April 1992, 11. 
personal income tax. ${ }^{19}$ The DIS was not open to ships beneficially owned in either of the two overseas dependencies of Denmark, Faroe Islands and Greenland.

In the long run, neither Norway nor Denmark were very successful in stemming the flagging-out process. Figures collected by Lloyds/Fairplay and analyzed by UNCTAD showed that in 1997 owners of ships in both Denmark and Norway each flagged about 58 percent of the tonnage of shipping in their home country, counting both the national and second registries as "home." By 2007, both countries had lost tonnage to foreign flags. By that year, Denmark owners flagged about 45 percent under Danish flags, while Norwegian owners only flagged about 28 percent of the tonnage under either of the first or second Norwegian registry. Neither the Danish nor the Norwegian registries made great efforts to attract foreign owners. By 1 January 2007, 97 percent of DIS by tonnage was owned by Danes; in NIS 61 percent was owned by Norwegians. ${ }^{20}$

The German second register ran into trouble with German organized labor from its beginnings. Germany had lost its overseas colonies at the end of the First World War, and thus, if the nation were to establish a second registry, it would have to be a domestic one along the lines of the Norwegian and Danish systems. As soon as the registry was established, 5 April 1989, German unions took the issue of the second registry to court, first to the Bremen Labor Court, and then to the European Court of Justice. The second register would allow ship owners to hire crews from other countries at their own prevailing labor rates, which German unions found a form of discrimination. Of a total German fleet of 276 vessels, 209 immediately moved to the second registry by $1990 .^{21}$

By 1995, organized labor, both inside Germany and internationally, continued to criticize the GIS second registry. The GIS was declared a "flag of convenience" by the ITF, following a German constitutional court decision in January 1995 that stated the system did not contravene the German constitution. The ITF blacklisting left the ships open to boycotts by union members in ports around the world, unless the ships met agreements with the ITF-affiliated German transport union, Offentliche Dienst, Transport und Verkehr (OTV). The declaration that the GIS was a flag of convenience followed a meeting by the ITF in Geneva in 1994. The ITF urged national affiliated unions like the OTV to declare their countries' second registries as flags of convenience. Most affiliated unions in countries with second registries did not do so, because they had already reached agreements with shipping companies guaranteeing negotiating rights and retaining some union members' employment on ships transferred to the second registries. At that point, only the Spanish Canary Island register had been similarly blacklisted in 1993 at the urging of Spanish unions.

The hard line by the ITF was attributed to the new general secretary of the ITF, David Cockroft. The federation claimed that the policy was a reponse to "continuing victimisation and harassment of seafarers by manning agents and certain ship owners" in

19 Bruce McMichael, "Special Report on Ship Registers: Newcomers seek share of the spoils," Lloyd's List, 8 September 1998, 6.

20 UNCTAD RMT, 2007, 36.

21 Edelgard Simon, "EC court to rule on German register," Lloyd's List, 20 October 1990, 5. 
the second registers. Despite the sentiment at the ITF headquarters, the ITF would only blacklist the remaining second registers on the approval of the national unions in the respective countries: Norway, Denmark, and Britain (for the Isle of Man registry.) None of the domestic unions in those countries had requested such action by early 1995 .

One ship, the Sea Nordic, registered in the German second registry, had been subject to a longshore boycott in the Danish port of Aarhus. The ship left port only half loaded. The owners later signed an agreement with the OTV, and paid some $\$ 100,000$ to cover back pay and ITF expenses. ${ }^{22}$ Shipping analyst Christopher Brown-Humes noted that the German register was suffering, because it had "less clearly defined aims," than those of Norway or Denmark, pointing out the drop in subsidies and the erosion of tax breaks for German shipping. ${ }^{23}$

The Italian second registry, like the German registry, encountered labor opposition while earning support from some of the Italian ship-owning establishment. However, Italy had more success in attracting ship owners. Italy, like Germany and Norway, has no overseas dependencies, and thus the system created there was a domestic one. When Italy's transport minister Publio Fiori announced that he intended to present a bill to the Italian parliament in late 1994 to initiate a second register, the statement was welcomed by the ship owners' association, Confitarma, even before the details of the bill were made public. Confitarma suggested that the new bill should be modeled on Norway's, which by that point, had some 70 percent of Norwegian beneficially-owned ships registered in the NIS second register. (That percentage was to fall severely, however, in later years.) ${ }^{24}$

Aldo Grimaldi, chairman of the Italian ship owners' association, said in April 1995: "There is no time to lose in creating a second register because the high cost of having to employ all-Italian crews is crippling the country's shipping sector. Italian shipping is in trouble because the costs it has to support do not allow it to be competitive on the international market." Grimaldi said he was "frustrated that other countries have already taken action, created second registers and have a competitive edge over Italian ship owners." He named Norway, Denmark, Britain and Germany as examples. "With our higher costs, sooner or later Italian shipping will disappear, unless certain drastic measures are taken. ${ }^{\circ 5}$ Like Germany, Italy had no overseas dependencies, and a domestic second register would be the only way one could be created.

One of the early successes of the Italian second registry was the transfer of the European cruise operator Costa Crociere from Liberia to the Italian second registry. In

22 Andrew Guest, "ITF blacks GIS-flag vessels: German owners face union boycotts," Lloyd's List, 13 March 1995, 1.

23 Christopher Brown-Humes, "Special Report on World Ship Registers: Striking a balance on quality and cost - Christopher Brown-Humes looks at the progress of 'second registers,"” Lloyd's List, 1 April 1992, 11.

24 Sarah Cunningham, "Italy may start second international ship register," Lloyd's List, 16 December 1994, 3.

25 Sarah Cunningham, "Competitive spirit vital for Italian shipping's survival," Lloyd's List, 7 April 1995, 5. 


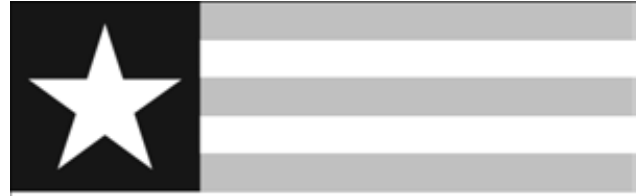

Liberia; red stripes, white star on blue. addition to a new flag ship, the Costa Atlantica, due to be handed over from Kvaerner Masa in June 2000, the company would transfer six existing ships, according to Costa Crociere chief executive officer and director Pier Luigi Foschi. Foschi estimated that operating costs would be about the same as under the Liberian flag, but that the Italian flag would add marketing value. Under the new Italian second registry, the profit tax was only 7.4 percent compared to the standard EU crew members each. ${ }^{26}$

Without making a concerted effort to attract foreign ships, the Italian register quietly succeeded in increasing the total number and tonnage of ships over the following decade. By 2007, Italy's combined first and second registry amounted to more than 13 million tons, just above the tonnage figures for the registries of the United Kingdom (including the Isle of Man), and the United States (including the Marshall Islands). Among the countries that had sought to establish a domestic second registry, Italy was the best at stemming the flagging-out process and at attracting total tonnage. ${ }^{27}$

Portugal and Spain both turned to their ancient offshore possessions in the Atlantic Ocean for the creation of second registries, emulating the British and Netherlands experience of using the semi-sovereign status of the offshore territories. Portugal established its second registry, the Madeira Open Shipping Register (MAR), under two laws passed in March 1989, formally opening the registry on 1 January 1990. Under the new laws, ships operating outside Portuguese territorial waters would not be liable to income tax on the profits, or on the salaries of crew and officers. By July 1990, four Portuguese ships had registered. Administrators and observers held high hopes for the flag, with its location in the Atlantic off the Straits of Gibraltar, convenient to shipping lanes.

Dr. Francisco Costa, the director of the Madeira Development Company, stated frankly that the purpose of the registry was to staunch the exodus of ships to open registries from the Portuguese flag. Costa recommended a change in the law which placed mortgage creditors last in line for collection of debts after employees and the government. He saw this provision as deterrent to international and Portuguese shipowners. However, he was confident the registry would continue to flourish. ${ }^{28}$

The Madeira Island registry was open to residents of the European Union and nationals of Portuguese-speaking countries elsewhere around the world. In addition, the

26 Giovanni Paci, "Costa Crociere re-flags to Italian second register," Lloyd's List, 28 December 1999, 1.

27 UNCTAD RMT, 2007, 36.

28 David Rudnick, “The register gets shipshape,” The Times (London), 20 July 1990. 
registry hoped to attract Spanish-owned ships. Spanish ship owners, like those in other European countries were re-registering their ships in open registry nations during the mid and late 1980s, and the Madeira flag hoped to compete, especially with a provision exempting all ships registered from income tax until 2011. ${ }^{29}$

Administrators of the Madeira registry were explicit in announcing that the registry's "first object was to stop the flagging out of Portuguese vessels to other flags." However, they also admitted that they sought to establish an open registry that would attract a variety of owners to a flag within the European Union. The number of ships in the registry climbed steadily and by 2004 the flag had 22 ships owned by Portuguese ship owners, 54 by Italian owners, 35 by Spanish owners, and 28 by German owners. However, the combined tonnage remained well below that of the major second registries and the competing open registers. ${ }^{30}$

Spain had faced problems very similar to those of the other European maritime states. Here, as in Germany, ship owners and organized labor took two different views of whether a second registry was a good solution. Registry of ships in Spain had fallen by two-thirds over the decade 1984-1993. As measured in gross registered tons (grt), the fall was from about 7.5 million tons to about 2.5 million tons. ${ }^{31}$ The idea of a Spanish second registry first was discussed as a legislative proposal in 1991. The law was passed in October 1992 and the registry opened later that year. ${ }^{32}$

In 1992, the ship owners' organization, Asociacion de Navieris Espanoles (ANAVE) reported that unless a workable second register was implemented the Spanishflag fleet could fall from 3.1 million grt to only 1million grt by 1996 with the loss of several thousand seafarers' jobs. ANAVE estimated a Canary Islands registry could save 6,000 Spanish jobs, and save the loss of an estimated $\$ 1$ billion per year in earnings to Spain. It was understood that under the new Canary Islands registry, the captain and first mate, and half the crew would have to be EU citizens. In order to bring benefits to the Canaries, it was suggested that an international banking center would have to be established there as well. ${ }^{33}$

As the Spanish law was under consideration, representatives of the ship owners' groups expressed some reservations about the new registry. It was not nearly as "liberal" as the other second registries that had been established, such as the Danish one, according to Fernando Casas Blanco, general director of ANAVE. Under the law as drafted, the corporate income tax would be dropped from 35 to 25 percent, and up to half the crew could be hired on an international basis. In light of these provisions, Juan Maria Gomez de Mariaca, chairman of tank shipping operator Repsol Naviera Vizcaina and a prior

29 The details of the Madeira ship registry may be found at: http://www.ecomadeira.com/DocumentLibrary/OperationalInfoGuidesAndProcedures/shipregistguide (accessed 8 August 2008).

30 "A very European register that flies the flag for Madeira," Lloyd's List, 12 March 2004, 11.

31 Andrew Guest, "Canaries register blacklisted," Lloyd's List, 11 February 1993, 1.

32 Ibid.

33 Fiona Gibson, "Special Report on the Canary Islands: Second register may be too little, too late," Lloyd's List, 2 December 1992, 9. 
chairman of ANAVE, disliked the idea that the ship registry law was part of a package designed for the Canary Islands, rather than an independent piece of legislation. He predicted that tensions between the people of the islands and Madrid would lead to delays and a half-hearted implementation. ${ }^{34}$

Within a year of the establishment of the system, Spanish labor unions protested to the ITF. The Canary Islands registry was placed on the ITF blacklist as a flag of convenience, the first of the second registers to be so designated. ${ }^{35}$

By 1994, despite a Socialist victory in the Spanish national elections and political promises to address the problems with the Canary register, there were still only five ships registered there. ${ }^{36}$ Spain offered tax concessions in 1996 that appeared to help. ${ }^{37}$ Even so, the reality turned out to be even worse than the earlier dire predictions of ANAVE representatives. By 1 January 1998, over 88 percent of Spanish-owned ships flew foreign flags. Including the Canary Island registry, the nationally registered ships dropped to considerably less than a half-million gross registered tons. ${ }^{38}$

Turning from the European experience to that of the United States, the issues took a slightly different form. The United States merchant marine had been in great decline since the Second World War, and labor unions had fought unsuccessfully to have the National Labor Relations Board extend jurisdiction to American owned ships registered in Panama and Liberia. ${ }^{39}$

The reaction of the United States to the proliferation of flags of convenience and the loss of shipping to overseas registry was complicated by the fact that the United States had a policy since the Second World War of "Effective United States Control (EUSC)." This doctrine had emerged during that war, when the War Shipping Administration had established direct control over a vast fleet of merchant ships registered in a wide variety of countries, through charters and other arrangements.

In the period of the Cold War, U.S. maritime administrators and naval personnel formalized the concept that certain American-owned ships, registered in friendly states, such as Panama and Liberia, could be counted upon to assist in transport of materiel in time of war, either through requisition or through charters. Thus Panama and Liberia were designated as "EUSC" countries. However, as political conditions in both Panama and Liberia often turned in anti-American directions, the reliability of such "effective control" flags came to be seriously questioned. ${ }^{40}$

34 Herbert Fromme, "Special Report on Spanish Maritime Industries: Owners welcome State Plans for Second Register," Lloyd's List, 7 May 1992, 9. Andrew Guest, “Canaries register blacklisted,” Lloyd's List, 11 February 1993, 1.

36 John Tavner, "Special Report on Spanish Maritime: Size of fleet faces critical decline," Lloyd's List, 11 May 1994, 11.

37 Bruce McMichael, "Special Report on Ship Registers: Newcomers seek share of the spoils," Lloyd's List, 8 September 1998, 6.

38 UNCTAD RMT, 1998, 30.

39 Carlisle, Sovereignty for Sale, 152-171.

40 Carlisle, Sovereignty for Sale, 193-216. 
Thus, as advocates of a new second registry for the United States sought the establishment of a new flag, it was less in hopes of preserving the American merchant fleet or sustaining employment of American merchant mariners. Rather, they sought an overseas jurisdiction under which ships could be registered, where they could operate competitively in the world market, and at the same time meet national security goals for a reliable fleet in times of military need.

Captain Warren G. Leback, Administrator of the U.S. Maritime Administration, argued in 1991 that in the wake of Desert Storm the United States should consider establishing a reliable second registry. Just such a development took place, without much public notice, over the next two years. ${ }^{41}$

The United States had no overseas colonies, but it did maintain, well into the 1980s, jurisdiction over certain Pacific islands as "Trust Territories." These island groups had been occupied by Japan prior to the Second World War II, and were still administered by the United States under United Nations authority. Under the Compact of Free Association signed with the United States in 1986, the Marshall Islands gained full sovereignty over domestic affairs, citizenship, and such legislation as its internal maritime and labor codes, while delegating the handling of some foreign affairs and all

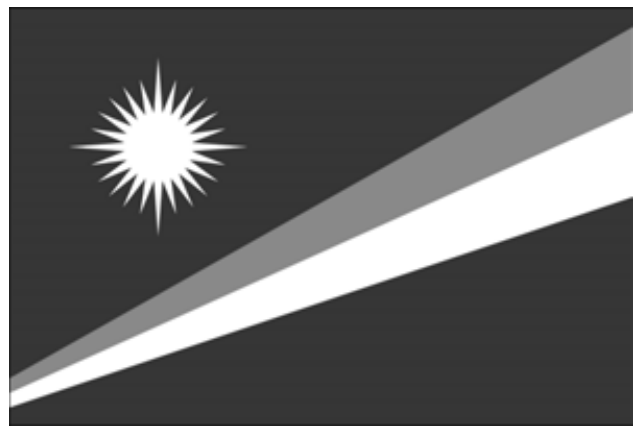

Marshall Islands, orange and white on blue.

defense to the United States. The new Republic of the Marshall Islands (RMI), with about 60,000 citizens, was entirely dependent on an aid package from the United States. RMI provided a suitable semi-independent sovereignty for a second registry along the lines of the Isle of Man, the Netherlands Antilles, and the other offshore second registries. ${ }^{42}$

International Registries, Incorporated (IRI), the successor company to Liberian Services Company established in 1948 under the leadership of Edward Stettinius, worked with the newly semi-sovereign Marshall Islands to establish a new registry, set up in 1992. The EUSC concept was explicitly noted during the creation of the system. The Marshall Islands provided assurance for available U.S. sealift capability, one of the reasons why the new registry was considered a second registry for the United States by UN observers and other maritime analysts. ${ }^{43}$

41 Andrew Guest, "U.S. furore over talk of second register," Lloyd's List, 13 September 1991, 8. Conversation by the author with Captain Warren Leback on 8 June 2009. Leback advocated that position at the time and now regards the development of the Marshall Island registry as a good development from the point of view of American national security.

42 Compact of Free Association. The compact itself can be consulted at http://marshall.csu.edu.au. The official text of the Compact is U.S. Public Law 99-239, 14 January 1986.

43 William Gallagher, "The Progress and Goals of the Marshall Islands Ship Registry,” 25 May 2001, in Articles and Speeches, www.register-iri.com 
The Marshall Island registry received a boost in 1996 when Overseas Shipholding Group (OSG) a large U.S.-owned shipping firm with both open-registry ships in international trade and U.S.-flag ships in trades restricted to U.S.-flag vessels, shifted 27 vessels from Liberia to the Marshall Islands. OSG continued to register new vessels in the Marshall Islands, including large tankers. In a public announcement, the OSG stated that the political situation in Liberia, experiencing a brutal civil war, was behind its decision to switch to the Marshall Islands flag. ${ }^{44}$

As a result of the losses of registry from Liberia, the Liberian government threatened to sue IRI, foreshadowing a final split between IRI and Liberia. Liberia did not renew its fifty year contract that had originally been signed with Liberian Services Corporation as arranged by Stettinius. After a litigious struggle, on 1 January 2000, the Liberian registry was taken over by a new U.S.-based firm, Liberian International Corporation and Ship Registry, and IRI continued to operate the Marshall Island Registry. ${ }^{45}$

By 2002, the Marshall Island Registry included 270 ships of over 1000 gross registered tons. Of those ships, U.S.-based companies owned 87, German firms 70, and Greek firms owned another 54. Expansion of the registry included cruise ships, liquid natural gas transport ships, oil rigs, and yachts. ${ }^{46}$

As the Marshall Islands Registry grew, the Liberian registry stagnated in the period 1997-2002, slowly recovering tonnage and ships after 2004 as shown in table 3 . To some extent, the slow growth after 2002 reflected the attempt of Liberia to be selective in new registries to improve its ranking in the MOU regimes.

44 "FOCs in the News," no date, circa November 1996, MEBA Telex Times.

45 Robert Ward, "Special Report on World Ship Registers: OSG switch helps lift Marshall Islands," Lloyd's List, 11 February 1997, 7.

46 "Variety, Diversity Mark Recent RMI Registrations," Marshall Islands Report Vol. 12, No. 3 (May 2002) www.register-iri.com; Gallagher quoted in David Young, "Marshall Islands Proves Quality attracts Quantity," Shipping and Trade News, 19 April 2001, 1; "Marshall Islands Tonnage now at 11 Million," Press release, IRI, 25 May 2001; www.register-iri.com; "Marshall Islands Achieves 15 Million Gross Tons," Press Release, IRI, 11 December 2002, www.register-iri.com; William Gallagher, "The Progress and Goals of the Marshall Islands Ship Registry,” 25 May 2001, in Articles and Speeches, www.register-iri.com. 


\begin{tabular}{|l|l|l|}
\hline \multicolumn{3}{|c|}{ Table 3. } \\
\hline \multicolumn{3}{|c|}{ MARSHALL ISLAND AND LIBERIAN REGISTRIES 1997-2001 } \\
(1 January of year shown) \\
\hline & $\begin{array}{l}\text { Republic of Marshall Islands } \\
\text { dwt (millions) }\end{array}$ & $\begin{array}{l}\text { Liberia } \\
\text { dwt (millions) }\end{array}$ \\
\hline 2002 & 18.1 & 73.1 \\
\hline 2003 & 21.8 & 68.4 \\
\hline 2004 & 31.6 & 74.1 \\
\hline 2005 & 38.1 & 76.4 \\
\hline 2006 & 42.1 & 84.5 \\
\hline 2007 & 54.6 & 105.2 \\
\hline
\end{tabular}

Source: UNCTAD RMT 2002-2007

As the number of flags of convenience continued to increase in the 1990s, the second registers soon became part of the competition. Observers debated whether the second registries would evolve in the direction of elite, high quality registers, with good safety and labor records, or whether they would compete with the proliferating open registries that served as flags of convenience for substandard ships. Through the 1990s and first years of the twenty-first century, both types of developments took place. That is, some of the second registers became more like flags of convenience, becoming known for ships with disreputable labor and safety records. Others maintained very high standards, on a par with the standards of the traditional maritime nations.

Following protests from local unions, by 1996, the ITF had declared the second registries of Spain, Germany, and the Netherlands (in the Antilles), all as flags of convenience. Even so, the ITF found it increasingly difficult simply to criticize all open registries or all second registries as flags of convenience, since some open registry owners had good labor policies. Indeed, some open registry flags, whether second registers or not, had good reputations. ITF leader Cockroft said: "It is becoming harder and harder to just maintain a national flag versus foc stance, and therefore we are having to develop a policy which is more sophisticated and which looks firstly at where the ship is trading, and what its competition is." The old distinction between traditional registries and open registries, was becoming increasingly blurred. ${ }^{47}$ The fact that some second registers, like the Netherlands Antilles, openly sought non-Dutch ship owners, also showed there was no clear-cut distinction between second and open registries.

By 2005, it was clear that only some of the second registers had partially achieved their goals of preventing the transfer of home-owned ships to flags of convenience. On the other hand, most of them had also succeeded by attracting at least some owners from other countries. A look at the statistics of registry helps clarify the degree of success of the various registries.

47 Robert Ward, "Special Report on World Ship Registers: Distinctions becoming more blurred," Lloyd's List, 11 February 1997. 


\begin{tabular}{|l|c|l|}
\hline \multicolumn{3}{|c|}{ Table 4. } \\
\hline \multicolumn{3}{|c|}{ OPEN AND SECOND REGISTRIES, 2005 } \\
\hline Country & 2005 dwt of ships over 100 grt & $\%$ owned by nationals of the flag \\
\hline Open Registries & & \\
\hline Panama & $177,866,000$ & 0 \\
\hline Liberia & $76,372,000$ & 0 \\
\hline Bahamas & $41,835,000$ & 0 \\
\hline Malta & $30,971,000$ & 0 \\
\hline Cyprus & $31,583,000$ & 1.5 \\
\hline Bermuda & $6,206,000$ & 0 \\
\hline St Vincent and the Grenadines & $6,857,000$ & 0 \\
\hline Antigua and Barbuda & $8,383,000$ & 0 \\
\hline International or 2 $2^{\text {nd }}$ Registries & & \\
\hline Norway (NIS) & $21,265,000$ & 58.5 \\
\hline Marshall Islands & $38,088,000$ & $28.4 *$ \\
\hline Isle of Man & $12,073,000$ & $38.9^{* *}$ \\
\hline Denmark (DIS) & $8,859,000$ & 94 \\
\hline French Antarctic & $5,427,000$ & 32 \\
\hline Netherlands Antilles & $2,132,000$ & 28.9 \\
\hline
\end{tabular}

* per cent owned by U.S. nationals

** per cent owned by U.K. nationals

In 2005, as shown in table 4, the percentage of tonnage controlled by owners domiciled in the home country, or in the case of the Marshall Islands, in the United States, was very much higher than in any of the open registry countries such as Panama and Liberia. In the second register countries, the percentage owned by nationals of the home country ran from about 30 percent to over 90 percent, in the case of Denmark. On the other hand, in the registries of countries like Panama, Liberia, Malta, and Bermuda, nationals of the country owned none of the tonnage. Cyprus had a very few Cypriot owners. Some of the second registers were quite successful in registering large tonnage totals, most notably Norway and the Marshall Islands. These figures suggest that, in the competition for registry, at least some of the second registries were holding their own by 2005.

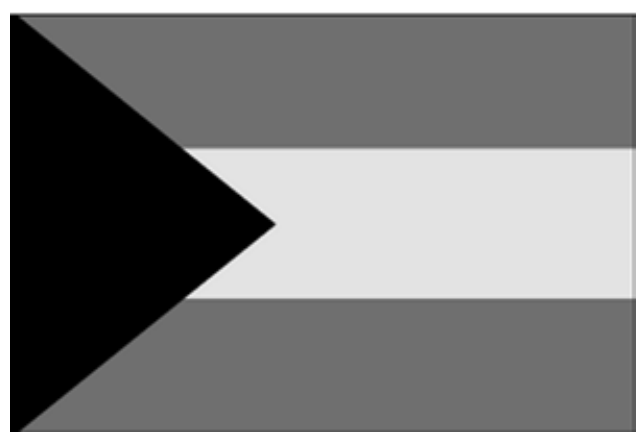

Bahamas; black with yellow stripe on blue.

However, all of the countries that developed second registries continued to have large numbers of ships registered under foreign flags of convenience. For example, by 2005 German-owned ships could be found in high percentages in the major open registers, and even the relatively successful Norwegian, Netherlands, and Danish second registers did not attract all owners from the home countries. These and other observations can be drawn from table $5 .^{48}$ 


\begin{tabular}{|l|l|l|}
\hline \multicolumn{3}{|c|}{ Table 5. } \\
\hline \multicolumn{2}{|c|}{ Percentage of ships owned, but registered under foreign flags 1997 and 2007 } \\
\hline & 1997 & 2007 \\
\hline Germany & 66 & 84.9 \\
\hline Spain & 80.79 & 79.23 \\
\hline Norway & 42.27 & 71.44 \\
\hline U.K. & 75.08 & 64.48 \\
\hline Denmark & 42.52 & 55.13 \\
\hline U.S. & 73.27 & 52.95 \\
\hline France & 44.41 & 51.98 \\
\hline Netherlands & 37.9 & 50.39 \\
\hline Italy & 36.29 & 27.58 \\
\hline
\end{tabular}

Source: UNCTAD RMT 1997, p. 29; 2007, p. 32.

When the percentages of foreign flagged ships owned by nationals of each of these nations are compared between 1997 and 2007 as in table 6 , the relative success or failure in preventing or discouraging flagging out can be measured. There were significant reductions in foreign-flag tonnage in both the United Kingdom and the United States, and a somewhat smaller decline in foreign registry in the case of Italy. However, foreign flagging increased significantly in Germany, Norway, Denmark, the Netherlands, and France.

\begin{tabular}{|c|c|c|c|c|c|c|c|c|c|c|}
\hline \multicolumn{11}{|c|}{ Table 6.} \\
\hline \multicolumn{11}{|c|}{ Number of vessels registered in open registry countries 2007} \\
\hline Domicile & Panama & Liberia & Bahamas & $\begin{array}{l}\text { Marshall } \\
\text { Islands }\end{array}$ & Malta & Cyprus & $\begin{array}{l}\text { Isle of } \\
\text { Man }\end{array}$ & $\begin{array}{l}\text { Ant. \& } \\
\text { Barb. }\end{array}$ & $\begin{array}{l}\text { St Vt. \& } \\
\text { Gren. }\end{array}$ & Bermuda \\
\hline Germany & 34 & 659 & 39 & 190 & 59 & 185 & 55 & 869 & 4 & 21 \\
\hline Italy & 10 & 19 & 8 & 2 & 39 & 3 & 2 & 0 & 19 & 0 \\
\hline Norway & 68 & 40 & 268 & 66 & 62 & 17 & 52 & 11 & 27 & 58 \\
\hline Denmark & 31 & 8 & 71 & 4 & 7 & 2 & 67 & 17 & 15 & 0 \\
\hline Netherlands & 33 & 42 & 34 & 1 & 5 & 23 & 1 & 16 & 7 & 1 \\
\hline $\begin{array}{l}\text { United } \\
\text { States }\end{array}$ & 145 & 105 & 166 & 191 & 8 & 22 & 5 & 7 & 27 & 29 \\
\hline $\begin{array}{l}\text { United } \\
\text { Kingdom }\end{array}$ & 43 & 34 & 86 & 10 & 8 & 25 & 90 & 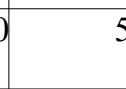 & 12 & 6 \\
\hline Spain & 58 & 0 & 11 & 2 & 17 & 8 & 0 & ) & 0 & 0 \\
\hline France & 12 & 3 & 14 & 0 & 4 & 0 & 2 & 2 & 17 & 7 \\
\hline
\end{tabular}

Source for table: UNCTAD RMT 2007, p. 39-40.

Table 6 demonstrates the degree of success of the Marshall Island registry in attracting American-owned ships. Clearly, by 2007 the Marshall Island registry was the leading overseas registry for American owned ships, attracting more than either Liberia or Panama. About 26 percent of tonnage of the Marshall Island registered ships was American-owned, with about 10 million dwt, due largely to heavy-tonnage tankers. Similarly, the 90 U.K.-owned ships in the Isle of Man registry represented about 38 
percent of the tonnage registered there. ${ }^{49}$

UNCTAD staff noted how the distinction between national fleets, open registries, and second registries was becoming very difficult to determine. The difficulty arose because national fleets registered foreign-owned ships, and second registries like that of the Netherlands, Norway, France, Isle of Man, and the Marshall Islands directly competed for international owners with such countries as Panama, Liberia, Cyprus, and Malta. ${ }^{50}$

Although the developments are complex as the world shipping picture changes, one can observe several trends and patterns of development after some twenty years of experience with second registries. All of the offshore second registries developed in the direction of open registries, much in the tradition of the original evolution of Panama and Liberia. All were located in insular dependencies of the home country.

Two of the offshore registries have become high-quality open registers: Isle of Man and the Marshall Islands. While attracting international owners, both of these flags have retained a substantial percentage of the home (U.K. and U.S.) fleets. Both might be ranked as second registry success stories.

Three offshore second registries have very explicitly attempted to become open registries, generating business and revenue for the insular state, but with somewhat less concern for maintaining high quality: Netherlands Antilles, Madeira, and Canary Islands. These three all had limited or marginal success. The French Kerguelen offshore second registry has been discontinued in favor of a domestic second registry. As noted, the experiment by Belgium of using Luxembourg registry was also soon abandoned, even though it received endorsement from Belgian labor unions. The German domestic second register ran into continued opposition from organized labor.

Denmark and Italy have had some success in convincing ship owners to remain under the nation's flag; while Germany and Norway have had more limited success, with the vast majority of domestically-owned ships still flagging out.

The analysis presented here suggests that the second registers did not entirely halt the problem of flagging out or the decline of the merchant fleets of the traditional maritime nations. The second registries were attempts to affect the changed dynamics in international shipping that only partially succeeded. The fact that several of them also evolved in the direction of open registries, accepting ships owned in a variety of nations, suggests that the underlying dynamics of the internationalization of the business are difficult to resist.

49 The figures for American-owned tonnage in thousands of dwt were: Liberia 3610, Panama 2278, Bahamas 10352, Marshall Islands 12889. Source: UNCTAD RMT 2007, p. 38-39. 